\title{
GALT Gene
}

National Cancer Institute

\section{Source}

National Cancer Institute. GALT Gene. NCI Thesaurus. Code C148332.

This gene plays a role in galactose metabolism. 